\title{
THE
}

\section{Female Headship and Women's Work in Nepal}

Pratistha Joshi-Rajkarnikar

Smita Ramnarain

University of Rhode Island, sramnarain@uri.edu

Follow this and additional works at: https://digitalcommons.uri.edu/ecn_facpubs

The University of Rhode Island Faculty have made this article openly available.

Please let us know how Open Access to this research benefits you.

This is a pre-publication author manuscript of the final, published article.

Terms of Use

This article is made available under the terms and conditions applicable towards Open Access

Policy Articles, as set forth in our Terms of Use.

\section{Citation/Publisher Attribution}

Pratistha Joshi Rajkarnikar \& Smita Ramnarain (2020) Female Headship and Women's Work in Nepal, Feminist Economics, 26:2, 126 159, DOI: 10.1080/13545701.2019.1689282

Available at: https://doi.org/10.1080/13545701.2019.1689282

This Article is brought to you for free and open access by the Economics at DigitalCommons@URI. It has been accepted for inclusion in Economics Faculty Publications by an authorized administrator of DigitalCommons@URI. For more information, please contact digitalcommons-group@uri.edu. 


\title{
Female Headship and Women's Work in Nepal Pratistha Joshi-Rajkarnikar and Smita Ramnarain ${ }^{\dagger}$
}

\begin{abstract}
Literature on household headship has, by and large, tended to homogenize female-headed households (FHHs). We present a mixed methods approach to disaggregating the experiences of female-headed households (FHHs) in the post-conflict period in Nepal. One of four households in Nepal is estimated to be female-headed, either as a result of conflict-related male deaths (de jure, or widow heads) or due to male out-migration (de facto, or wives of migrants). We examine similarities and differences in the work responsibilities and labor market participation of de jure and de facto female heads using quantitative data from the Nepal Living Standards Surveys (NLSS) and qualitative data collected through fieldwork in Nepal. While both types of households share some similar concerns, de jure and de facto female heads face different challenges in negotiating their everyday household and labor market roles. Findings inform policy interventions that can be specifically targeted toward each type of household.
\end{abstract}

Keywords: gender, female headship, mixed methods, South Asia

JEL codes: B54; B41, J16

\footnotetext{
* Research Associate, Global Development and Environment Institute, Tufts University. $\dagger$ Assistant Professor of Economics, University of Rhode Island, Kingston RI 02881. sramnarain@uri.edu
} 


\section{INTRODUCTION}

Through the 1980s and 1990s, concerns around feminization of poverty led to several studies seeking to find a correlation between female household headship, vulnerability to poverty, and socio-economic marginalization in developed as well as developing countries (Kossoudji and Mueller 1983; Rosenhouse 1988; Buvinic and Gupta 1997). While these studies have contributed to a greater understanding of nontraditional family structures, they have also pointed to the difficulties and dangers of using female headship as a signifier of poverty (Chant 2003, 2004). In addition, this body of work makes at least two further contributions to feminist economics. First, the processes of intra-household allocation observed within nontraditional family structures debunk simplistic correlations between household income and welfare. In some instances, even where female-headed households (FHHs) are poorer than male-headed households in terms of income (or assets), the well-being of children and household members is ensured through a more egalitarian intra-household distribution of resources. Despite poverty, a greater proportion of resources in FHHs may be allocated towards children's goods, calories, or protein-dense foods, leading to a nutritional status equal to or higher than in traditional households (Kennedy and Peters 1992; Kennedy and Haddad 1994; Onyango et al.1994; Handa 1996). At the same time, however, the wide variation in the ability of FHHs to ensure the well-being of family members observed in this literature highlights the necessity of disaggregating female headship rather than treating these households as a homogenous category (Varley 1996; Fuwa 2000; Ramnarain 2016). For instance, disaggregating FHHs using the conventional distinction between de facto and de jure heads (Youssef and Hetler 1983) reveals different forms of poverty that each must contend with, and which impinge on their respective abilities to improve agricultural productivity in Zimbabwe (Horell and Krishnan 2007). Similarly, Lingam (1994) examines how caste, class and gender hierarchies in India play a key role in how women heads cope with socio-economic situations in a context of structural inequality.

This study provides a disaggregated, contextual, mixed-methods analysis of the work responsibilities and constraints faced by de facto and de jure female heads of household in post-conflict Nepal. We use quantitative data from the Nepal Living Standards Survey (2011) (NLSS III) to identify differences in the work responsibilities and labor market participation between these two categories of female heads, as well as qualitative data collected through fieldwork in Nepal to shed light on the factors determining these differences. Such analysis contributes to existing literature on female headship through providing a better understanding of the processes and challenges de jure and de facto female heads face in their everyday lives and work. We find that while both types of households share some similar features and concerns, de jure and de facto female heads are placed differently in negotiating their household and labor market roles. 
The investigation presented here is valuable since disaggregating de facto and de jure FHHs allows for a closer examination of the implications of female headship for women's work responsibilities and labor market participation. The absence of a male head of household transforms women's responsibilities within and outside the household, but the nature of such a transformation is less clear, especially in developing country contexts. Women heads may spend more time working outside the home in self-employment or wage labor if they are sole income earners for the household, or if the absence of men increases women's autonomy (Sadiqui and Ennaji 2004). They may, however, also spend more time working on agricultural production (in own-use production as self-employed workers), rather than in wage labor, in contexts where they have replaced male labor in farming. As a third possibility, the responsibility for childcare or the care of dependents, prevailing gender norms, structural barriers to labor market access, or the existence of other sources of income (such as asset ownership or remittances) may lead to their lower participation in the labor market or in agricultural work.

This study divides women's work into four distinct categories: household work, self-employment in agriculture, self-employment in non-agriculture, and wage employment. Rather than only examine wage labor participation of female heads, such analysis looks into the overall work burdens of de facto and de jure heads respectively. Further, the use of quantitative and qualitative data to examine women's work in de jure and de facto FHHs permits some exploration of the causal processes behind the choices these women make, and the empowerment consequences of such work. For instance, while wage labor and market participation may augment women's autonomy through their access to cash, such gains in autonomy might be limited in cases where female heads have given up market work, i.e. where they decide to stay home to provide better care to dependents, or to enjoy more leisure time, or due to structural barriers in the labor market. Understanding the different constraints and challenges faced by each type of female head is key to designing suitable policy measures that address the structural inequalities and disempowerment that (different types of) FHHs face. Findings may be thus used to target policy interventions - especially those focused on an expansion of choice and opportunities, rather than simply incomes - specifically toward each type of household.

\section{DISAGGREGATING FEMALE HEADSHIP}

The categories of de jure and de facto FHHs have been adopted and developed by a number of studies on household headship (see Ruwanpura 2006; Islam 1993; Youssef and Hetler 1983). De jure headship occurs when women have taken on the role of household heads on account of the desertion of, divorce, or legal separation from, or the death of their male partners. Chant (1997) defines de jure households as those 
'where women live without a male partner on more or less a permanent basis and receive no economic support from one except in the form of child maintenance' (p. 15). De facto female headship, on the other hand, is temporary and usually occurs when women's male partners are absent due to migration, widespread civil conflict or desertion or in households where the male partner's contribution to economic maintenance is marginal due to sickness, disability, unemployment etc. (Youssef and Hetler 1981, 1983).

Scholars have drawn attention to the difficulties and paradoxes associated with such a categorization. For one, such a categorization may be too simplistic. Chant (1997:15) points to the difficulty of making generalizations about either category. Although de facto households are 'temporary' heads of household, some de facto women heads may be spending more time on their own than de jure heads. Second, there is immense variation even within these de facto and de jure categories of FHHs on the basis of class, religion, region, caste, marital status and/or the social context of female headship. Ruwanpura (2006) finds, for example, that kinship networks in particular ethnicities can significantly determine the degree of autonomy of a FHH in Sri Lanka. Such variations make an intersectional analysis of headship crucial. Similarly, even within de jure FHHs, whether the female head is a widow, a divorcee, or has been deserted can be of significance in determining the extent of support available to her from relatives (Folbre 1991). Finally, the distinction between de jure and de facto households may be hard to draw in terms of data collection. For instance, de facto headship may arise in the course of female headship becoming de jure, as when migration of husbands might lead to them abandoning their wives after a period of time (Chant 1997: 17-18). The issue of headship may be especially problematic if cultural norms prevent women from being accorded the status of household heads despite being the primary maintainers and supporters of the household. Chant (1997) argues, therefore, that women-maintained might be a better term than female-headed. Surveys and censuses, therefore, can only capture headship at a point of time and not the dynamic processes by which headship is often determined.

We acknowledge these difficulties associated with using survey data on female headship. Despite these caveats, some useful information can be obtained on the livelihood and survival strategies employed by de facto and de jure female heads, their work activities, and their time allocation between domestic (household) and market-based work. Further, qualitative data serves to confirm and triangulate findings emerging from quantitative analysis.

\section{De jure headship in Nepal}

Nepal recently emerged from a decade-long violent civil conflict (1996-2006) between the Maoists and the erstwhile monarchy, paving the way for a transition to multi-party democracy. The death toll was estimated to 
be around 17,265 (Nepal Monitor 2011), with a large number reported as 'disappeared'. An increase in the number, proportion, and visibility of FHHs has frequently been documented in war-torn or post-war societies due to high levels of male mortality or high(er) rates of male out-migration from conflict-affected areas (Zuckerman and Greenberg 2004; Ruwanpura 2006). In Nepal, de jure headship may not be attributed solely to the conflict due to the lack of data to confirm such speculation. Anecdotal evidence does emerge, however, that indicates a greater presence of de jure female headship, especially widow headship, in the post-conflict period (Yadav 2016; Menon and Rodgers 2015).

De jure female headship in the aftermath of complex emergencies has received some specific attention in recent literature. Studies have reported the unique circumstances and constraints de jure heads face in various contexts of violent conflict or natural disaster, on account of their gender and marital status. Brück and Schindler (2008) draw specific attention to widowhood as a large-scale phenomenon in conflict-affected societies and discuss the particular difficulties they face in coping with chronic insecurity, loss of livelihood and economic adversity in the immediate aftermath of violent conflict. Zuckerman and Greenberg (2004: 74) comment on how macroeconomic policies - cutbacks in expenditure - in post-conflict transitions have inadvertent effects on widows and new single mothers by depriving them of public support. Rehn and Sirleaf (2002) comment on the lack of access widows have to their husband's land, assets, credit, and other productive resources (especially in the absence of sons) due to outdated inheritance laws, social pressure, or discrimination. In Rwanda, for instance, female heads in the post-genocide period were vulnerable to the expropriation of their husbands' land, or had a hard time gaining access to their family's land (Turshen 2001; Newbury and Baldwin 2000). The discrimination de jure heads face in many patriarchal societies may also mean a lower standard of living for their households compared to others (Nowrojee 1996).

In the South Asian context, examining female headship in the post-war period in Sri Lanka across Tamil, Sinhala and Muslim households, Ruwanpura and Humphries (2004) find that de jure and de facto heads may share similar economic concerns, ethnic differences do matter in the social resources each is able to mobilize. Ruwanpura (2006) also finds that de jure heads are especially dependent on the participation of children in domestic as well as in the labor market, and on kin support. In Nepal, Galvin (2006) looks into the constraints on widows' mobility and other social restrictions around public participation. She notes their limited access to land and inheritance and their vulnerability to abuse and exploitation if perceived to be without 'male protection.' More recently, Yadav (2016) explores changes in the cultural practices surrounding widowhood in Nepal, in the period after the Maoist conflict. While Galvin (2006) and Yadav (2016) explore cultural norms around widowhood and their subversion, Ramnarain (2016) uses ethnographic data to examine the post-conflict economic circumstances of widow household heads in Nepal, 
and the processes by which they mediated social institutions and patriarchal norms in their everyday struggles for survival. Ramnarain (2016) finds while widow heads tended to be asset-poor and preferred not to raise issues relating to land ownership with their kin, their coping strategies ranged from selling smaller assets (jewelry and livestock) to taking up market work. The need to focus on de jure female heads is motivated by the fact that the long-term planning and survival strategies of such households are likely to differ from the strategies of de facto female heads whose husbands are likely to reappear (Ruwanpura 2006). It is likely that the avenues of employment and opportunities available to de jure heads, as well as their work burdens, are very different - especially on account of the social and cultural milieu in which they are placed as a result of widowhood, abandonment, divorce, or separation - than women heads of household that have a nonnegative probability of their husbands showing up.

\section{De facto headship and migrant households in Nepal}

While violent conflict may have contributed to a rise in de jure headship due to male mortality or increased separation rates, migration has played a central role in the Nepalese economy, leading to a large number of de facto female heads. ' One out of every eleven Nepalese adults is in foreign employment and more than half of the households in the country receive remittances. With remittance inflows accounting for nearly a third of the country's GDP in 2014, Nepal ranks third in the world in terms of remittances received as a percentage of GDP. Remittance is the biggest source of foreign funds; in 2014 total remittances received (USD 5.8 billion) was greater than the sum of Overseas Development Assistance (ODA) (USD 870 million) and Foreign Direct Investment (FDI) (USD 30 million) inflows. Much of Nepal's economic progress, including reduction in poverty and increments in literacy levels - even through the conflict years - is attributed to remittance inflows rather than structural changes or development efforts of the government.

Labor migration from Nepal is heavily gendered; almost 92 percent of the country's labor migrants are men (NLSS 2010/11). About 50 percent of these men are in the age group 15 to 29 years and another 38 percent are between 30 to 44 years. This male-dominated migration has contributed to an increase in the number of female-headed households: about 48.7 percent of migrant households are headed by women, compared to 16.9 percent for non-migrant households.

Scholars focusing on the impact of male migration on families and communities left behind argue that men's migration could fundamentally change gender relations and transform the socio-cultural beliefs that characterize traditional gendered practices (Howell 2002; Cohen et al. 2008). However, in terms of women's work burdens as a result of de facto headship, a consensus does not yet exist. Some evidence exists that men's migration may create shortages in labor supply and increase women's participation in market work 
(Lipton 1980). Other evidence points to the empowerment effects of male outmigration on women: women may participate more in market work due to greater autonomy, mobility and freedom due to the absence of male supervision (Sadiqui and Ennaji 2004). As another possibility, women may face increased household and childcare responsibilities in the absence of men, but without corresponding changes in their status in the household hierarchy (Brown 1983; Jetley 1987). Male outmigration may also limit women’s mobility in public spaces, or discourage their employment outside the home, due to increased scrutiny over their whereabouts in the absence of their husbands or because women may be more vulnerable to harassment by other men who believe that there is no one to protect the woman when her husband is away (Adhikari and Hobley 2015; Acosta 2006). Remittance income may play a role here by weakening women's willingness to participate in market work and keeping them financially dependent on their husbands (Acosta 2006).

Studies on migration from Nepal mainly focus on the benefits of migration, such as poverty reduction through remittance inflows and reduced unemployment pressures through outflow of workers (see Lokshin et al. 2007; Acharya \& Leon-Gonzalez 2012) but its gender consequences have been largely neglected in academic literature as well as in migration-related policymaking. The only study that looks into gender impacts of migration for Nepal, using quantitative analysis, is a World Bank study by Lokshin and Glinskaya (2008), which examines the effects of de facto female headship on women's participation in labor market using the Nepal Living Standard Survey 2003/04 (NLSS -II) data. The study finds that women in remittancereceiving households have lower market participation than women in households that don't receive remittances. This study does not explore causal factors or the processes by which intra-household power relations are impacted due to men's migration on women's willingness or ability to work. Also, by focusing only on market participation, it neglects looking into changes in women's overall workload during men's absence.

Other studies on the gendered impacts of migration in Nepal are based on qualitative or ethnographic research based on smaller, region-specific samples. Kasper (2005) examines changes in gender relations among Gurungs in the Kalabang village of Kaski district using semi-structured interviews with women. She finds that women's overall workload as well as decision-making power increases during men's absence, with this increase being higher for women in nuclear households. Maharjan et al. (2012) look into two districts Syangja and Baitadi - and find that women's experiences depend on remittances: while women receiving large remittances could experience a decline in workload (as they may be able to hire labor) and an increase in decision-making, women receiving smaller remittances could be burdened with more work. Adhikari and Hobley (2015) find, in Khotang and Udaypur districts, that while men's migration results in intensification of women's domestic work, the impacts on economic participation are unclear since they may be mediated by 
caste or income group. While these studies provide interesting insights into women's status in specific regions, they don't provide much information in the differences in women's experiences across regions. Findings pertain to women in migrant households, and not necessarily to de facto female heads specifically. Further, since all three of these studies are based on the Hill districts of Nepal, they fail to illustrate the differences in women's experiences based on the vastly different gender and socio-cultural norms between the Hill and Terai (plains).

Besides migration, de facto headship may also arise in cases where women are the primary earners and maintainers of their households due to the sickness, disability or incapacitation of their male spouses. In such cases, the spouse could reside within the household, but not be the primary decision-maker or earner. In post-conflict situations, it is possible that injury or ill health leads to a large number of such de facto heads (Datta and McIlwaine 2000). Another circumstance leading to de facto female headship is polygamy, in societies where it is culturally acceptable. In such circumstances, women may receive varying amounts of monetary and non-monetary support from the husband or kin networks, despite having a separate household. In all of these cases, women emerge as the primary decision-makers and/or earners for the household and as a consequence, may face increased responsibilities in the domestic and market spheres.

Using the NLSS data allows us to go beyond existing studies in comparing the work burdens and allocation of de jure and de facto female heads in Nepal, as well as to generalize the findings to the rest of the country. In addition, qualitative data collected through fieldwork allows us greater insight into the challenges faced and the coping strategies used by women as they take on the role of household heads in a patriarchal society.

\section{DATA, FIELDWORK AND METHODS}

In order to examine the differences in work responsibilities of de jure and de facto female heads, we employ a mixed-methods strategy including econometric analysis using the NLSS (2011) and qualitative analysis based on fieldwork, conducted in 2008/09 and 2011 (by <insert Author 2>) and in 2014 (by <insert author $1>)$.

\section{Description of secondary data: NLSS-III}

The NLSS-III is a nationally representative survey of 28,670 individuals from 5,598 households. Of these households, 26.7 percent are female-headed. ${ }^{2}$ The survey includes 10,288 women, of whom 15.5 percent $(1,599)$ are the heads of their households. Our analysis here is based on this subsample of 1,599 female heads. Here, we differentiate between de jure and de facto heads based on their marital status, where 
married heads are defined as de facto while those female heads who are widowed, separated, divorced or unmarried are de jure heads.

In our sample of 1599 women, about 67.5 percent women are de facto heads (1080) and the remaining 32.5 percent (519) are de jure heads. Out of 519 de jure heads, widow heads constitute the majority (75 percent), while the rest are separated, divorced or never married. ${ }^{3}$ Among de facto household heads, $78.7 \%$ belong to migrant households. Out of the remaining 225 women (21.3\%), 59 do not live with their husbands but are reported as married. It is possible that their husbands are internal migrants who come home often and are therefore not reported as migrants. Although a punishable offense, polygamy does prevail in Nepal ${ }^{4}$. It is possible, therefore, that some women are de facto heads if their husbands are living with a second wife without a legal separation from the first. The remaining 166 women live with their husbands (husbands being reported as the spouse of the household head in the survey). In this case, it could be that the husbands are sick or disabled and the woman is the primary provider for the family. Tables 1 and 2 provide some descriptive statistics on these disaggregated groups of female heads of household.

\section{INSERT TABLES $1 \& 2$ HERE}

The survey provides information on time spent by women on household work as well as their involvement in wage-employment and self-employment activities. Though information on the number of hours spent on self-employment and wage-employment activities in a week is available in the survey, we use a binary variable indicating whether women participate in a particular activity or not. This is because we are interested in examining what factors are important in determining women's ability and decision to take up incomegenerating activities. Also, since data on time spent on all other activities during the week, accounting for all 168 hours of the week, is not available, it is infeasible to conduct a full-fledged time-use analysis. Data on women's individual characteristics (age, education), household characteristics (structure, age and sex of household members, asset and land ownership, caste) and regional characteristics (urban or rural, ecological belt) is also provided by the survey. In examining the differences in women's work responsibilities, we control for the impact of these other factors on women's work.

\section{Fieldwork description}

This study utilizes observations and data collected through field research by both the authors in the space of a few years. <Author 2> carried out fieldwork in Nepal in different phases between 2008/09 and 2011 to examine widow headship in conflict-affected regions, while <Author 1's> fieldwork in 2014 explored the experiences of migrant wives and de facto heads of households. 
The field research carried out by < Author 2> in 2008/09 sought to explore the coping strategies of widow heads in the post-conflict period, in Kathmandu valley and mid-western districts of Rolpa and Dang, where the fighting during conflict had been most severe. The choice of these locations emerged from the large presence of widow-headed households as well as a significant number of NGOs working with widows on relief, rehabilitation, and development. The information gathered through these interviews and FGDs was supplemented by formal and informal conversations with government officials, international, and local NGO representatives and fieldworkers in Rolpa, Dang, and Kathmandu Valley (a total of 48). In 2011, widow heads of household from the eastern districts of Morang and Sunsari and from the west-central districts of Dhading, Tanahu, and Chitwan were included in the study. As part of the study, in-depth interviews - each lasting several hours, and aimed at collecting partial oral histories of widow heads' survival and livelihoods strategies, their experiences with post-conflict reconstruction programs, and their negotiation of socio-cultural norms in the aftermath of war - were carried out with 32 widow heads of household in total. In addition, eight focus group discussions were held with groups of widow heads as well as non-widows in these areas, each consisting of between 8 to 14 participants.

Field research by <Author 1> in 2014 consisted of interviews with 178 migrant wives, 100 of whom were de facto heads of household. The fieldwork was conducted in four districts in Nepal, with two of the research districts being from the Hill region (Syangja and Rolpa) and the other two from the Terai (Chitwan and Siraha), partly to compare differences in women's experiences based on the different socio-cultural norms between the Hills and Terai. Within each ecological zone, one district with high development and women's empowerment index (Syangja and Chitwan) and another district (Rolpa and Siraha) with low values for both these indices were selected. ${ }^{5}$ The survey questionnaire was semi-structured and included questions on women's individual and household characteristics such as women's age, education level, caste, ownership of assets and household structure along with more open-ended questions on women's experiences during their husbands' absence in terms of their work responsibilities, their decision-making and their social participation.

\section{WORK BURDENS OF FEMALE-HEADED HOUSEHOLDS IN NEPAL: FINDINGS}

We now turn to the analysis of women's work burdens, through quantitative analysis of the NLSS-III data, and findings from field research.

\section{Model and variables}


In order to look into differences in women's household work responsibilities, we conduct Ordinary Least Squares (OLS) estimation for the following model using the NLSS-III data:

$$
\text { Model 1: hh_work }=\beta_{0}+\beta_{1}(\text { de jure or de facto head })+\beta_{2} X_{i}+\varepsilon_{i}
$$

where, $h h_{-}$work is a continuous variable representing hours spent on household work and is defined as:

$$
\begin{aligned}
& \text { hh_work Hours spent on (Fetching water }+ \text { Collecting firewood + Collecting fodder }+ \text { Animal } \\
& \text { care }+ \text { Knitting /tailoring }+ \text { Processing preserved food }+ \text { Household repair }+ \\
& \text { Cooking/ Serving food + Clearing house + Shopping + Caring for elderly/sick + } \\
& \text { Child care }+ \text { Community service/volunteering) }
\end{aligned}
$$

In order to look into differences in women's participation in self-employment and wage-employment activities, we conduct a multivariate probit estimation (Young et al. 2009) for the following three models:

$$
\begin{aligned}
& \text { Model 2: } s_{-} a g=\beta_{0}+\beta_{1}(\text { de jure or de facto head })+\beta_{2} X_{i}+\varepsilon_{i} \\
& \text { Model 3: } s_{-} n_{-} a g=\beta_{0}+\beta_{1}(\text { de jure or de facto head })+\beta_{2} X_{i}+\varepsilon_{i} \\
& \text { Model 4: wage }=\beta_{0}+\beta_{1}(\text { de jure or de facto head })+\beta_{2} X_{i}+\varepsilon_{i}
\end{aligned}
$$

where $s_{-} a g, s_{-} n_{-} a g$ and wage are dummy variables, representing women's participation in self-employment in agriculture, self-employment in non-agriculture, and wage-employment, respectively. Each of these variables are defined as follows:

S_ag Binary variable with value 1 for any woman who has spent at least an hour in the past week working in family-owned field for no wages, and 0 otherwise.

s_n_ag Binary variable with value 1 for any woman who has spent at least an hour in the past week working in family-owned business or home-production, and 0 otherwise.

wage Binary variable with value 1 for women who are employed in agricultural or nonagricultural activities and received wages or in-kind payments for this work, and 0 otherwise.

The use of multivariate probit is appropriate here since it is likely that the dependent variables in models 2 , 3, and 4 are correlated (Chib and Greenberg 1998; Capellari and Jenkins 2003). An individual involved in one of the three activities could be less likely to be involved in the other two due to time constraints. Also, women who are able to participate in income-generating activities, such as wage-employment or selfemployment in non-agriculture, may be less likely to do subsistence agricultural work that does not bring in monetary income. In our sample here, of the 213 women involved in self-employment in non-agriculture only 7 percent also took up wage employment, and about 20 percent were involved in self-employment in agriculture. Of the 224 women involved in wage-employment activities, about 27 percent also spent some time in self-employment in agriculture, and only 6 percent took up self-employment in non-agriculture. 
Our key independent variable, de facto head is a binary variable with value 1 for de facto heads and 0 for de jure heads. $\mathrm{X}_{\mathrm{i}}$ is a vector of individual (age, education level), household (presence of other adult female members, presence of adult male members, number of dependent members, asset index ${ }^{6}$, land ownership, caste) and regional (urban or rural, ecological belt) characteristics. In the models above, $\beta$ is the parameter corresponding to each $\mathrm{X}$ and $\varepsilon$ is the stochastic component.

\section{INSERT TABLE 3 HERE}

A woman's age and her education may indicate her position in the household and her work responsibilities. Women are expected to take on more responsibilities as they get older, but after a certain age some of these responsibilities may be transferred to younger women in the household. We expect a quadratic relationship between women's work and their age, with the coefficient for age being positive and that for age-squared being negative, for all four models. Women with higher education are more likely to be employed for wages: we expect a direct relationship between education and employment in income earning activities (wageemployment, self-employment in non-agriculture) and an inverse relationship between education level and unpaid domestic or subsistence farming work.

The variable 'presence of other adult female members' is only included in the models 1 and 2 since women living in the same household may be able to share domestic and subsistence farming responsibilities. Household heads may also transfer some of their responsibilities to younger female members. Hence, women's domestic work and self-employment in agriculture is likely to decline in the presence of other adult women in the household. The variable 'presence of adult male members', on the other hand, is only included in models 3 and 4 since women may be discouraged from taking up market work (self-employment in non-agriculture or wage-employment) which involves stepping into public spaces, in the presence of an adult male member to take up these tasks. Increase in the number of dependent members could mean higher domestic work (carework) for women. It could also increase the need to be employed in wage-earning activity to be able to provide for the dependent members. Hence, women's domestic work as well as their participation in market work is likely to increase with the increase in the number of dependent members.

The variables asset index, land ownership, and caste are included as indicators of women's class and economic status. Women from wealthier families (higher asset index) are less likely to be employed in income earning activities, partly because the need to take up market work may not be as immediate as that for poorer families and partly to maintain their social status (Klasen and Pieters 2015). Women from 
wealthier households could hire help for domestic and agricultural work and have better access to running water, electricity, and cooking fuel, thus eliminating tasks like fetching water and firewood, so they are expected to have less household and agricultural work. Greater ownership of land is also an indicator of higher economic status. But women in households with more land may be involved in farming, rearing animals, or processing agricultural products. Higher land ownership is thus likely to be associated with more domestic and agricultural work for women and lower land ownership could push women to take up selfemployment in non-agriculture or in wage-employment.

High-caste women may face more restrictions on their mobility in public spaces: they are expected to have more household work, higher participation in subsistence agriculture and lower participation in wageemployment and self-employment in non-agriculture. However, the relationship between caste and women's work may not be as simple. Women from high caste groups could be from wealthier families and have greater access to education and employment opportunities. To account for this condition, we include two interaction terms: caste with education, and caste with asset index. We would expect women from high caste family with more education to be employed in income-earning activity. Participation in income-earning activity for high-caste women from wealthy families is, however, not as clear since being from a wealthy family may reduce the need to take up market work, but greater access to employment opportunities and access to capital to invest in smaller business ventures may encourage them to participate in market work.

Women in rural areas are likely to face higher burden of domestic work as access to resources such as water, electricity, and gas are more limited in rural areas. Most rural households are involved in subsistence agriculture, indicating higher participation in self-employment in agriculture for rural women. Participation in wage-employment or in self-employment in non-agriculture is likely to be lower for rural women because of their limited access to markets and to employment opportunities in the manufacturing or services sectors.

Ecological zone is included in the models to capture the differences in women's work due to socio-cultural differences across geographic locations. Nepal is divided into three ecological zones running across North to South and stretching from East to West. The Mountain region on the North consists of high hills and mountains, the Terai region in the South consists of plains, and the Hill region in between consists of midhills and valleys. Among the three ecological belts, gender inequality is higher in the Terai because the social norms in this region are highly influenced by conservative Hindu beliefs that encourage patriarchy. Social norms in the Hills and Mountains are less restrictive for women due to Tibeto-Burman influences (Bennett and Acharya 1983). Women in Terai are thus expected to have higher domestic work, greater participation 
in self-employment in agriculture, and lower participation in wage-employment or in non-agricultural selfemployment.

\section{Model results}

Here we present the findings for the four models outlined above, in five parts. First, we present analysis of work responsibilities for all de facto and de jure heads. We then present the same models, excluding de facto heads living with their husbands, followed by a disaggregation of de facto households based on whether they belong to migrant households or not. The fourth part includes only de facto heads, and tests for differences in work responsibilities based on whether women live with their husbands or not. Finally, we look into whether the type of de jure headship (widows vs. women who are separated, divorced or never married) matters for women's work.

\section{- Comparing all de facto heads with all de jure heads}

Here, de facto heads are married female heads while de jure heads are female heads who have been widowed, never been married, are divorced or separated.

\section{INSERT TABLE 4 HERE}

The model on household work (model 1) explains about 27 percent of the variation in hours spent in household work for female heads. The coefficient for de facto head is positive and statistically significant for this model: de facto heads are likely to spend more time on domestic work than de jure heads. The coefficients for age, wage-employment, presence of other adult female members, number of dependent members, and asset index are statistically significant and consistent with our expectations. The results also indicate that women from rural areas and women in the Hill region spend more time on household work. Coefficients for variables years of education, land ownership, caste, and the two interaction terms (caste and education, and caste and asset index) are not statistically significant for this model.

We also see in Table 4, that the coefficient for de facto is positive for model 2 and negative for models 3 and 4, and these coefficients are statistically significant in all three models. This indicates that de facto heads are likely to be self-employed in agriculture, most of which is unpaid. De jure heads, on the other hand, are likelier to take up wage-employment and self-employment in non-agriculture, both sources of monetary income. The lower participation of de facto heads in income-earning activities could be due to some financial support from their husbands. De jure heads, on the other hand, take up income-earning activities as primary providers for their families. 
The coefficients for age and years of education are consistent with our expectations for all three models, though the coefficients for years of education are not statistically significant. Also, the coefficients for the variables on household structure (presence of adult male, other female or dependent members) are not statistically significant in any of the three models. We see that women from wealthier families (higher asset index) are more likely to be employed in self-employment in non-agriculture and less likely to be doing subsistence agricultural or wage-labor activities. And, women in households with greater land ownership are more likely to be self-employed in agriculture and less likely to take up wage-employment or selfemployment in non-agricultural sector. These findings are consistent with our expectations.

The results show that high-caste women are less likely to take up wage-employment activities. The coefficients for the interaction terms for caste and education, and caste and asset index, are not statistically significant in any of the models. Women from rural areas are more likely to take up subsistence agricultural work and less likely to be involved in self-employment in non-agriculture or wage-employment, as expected. Women from Mountain and Hill regions are likely to have higher participation in both self-employment and wage-employment activities than women in Terai region; however, the coefficients for these two variables are only statistically significant for the model 2 . $^{7}$

The estimates for the correlation coefficients for the unobservable factors between the three sets of equations (rho) are negative and statistically significant, indicating that participation in one of the three employment activities makes participation in the other two less likely. The Wald statistic for the test of the hypothesis that correlation coefficient between the unobservables in the three models $(2,3$, and 4 ) equals zero is 43.167 . So, the hypothesis of independence between the stochastic variables in the three models can be rejected. The use of multivariate probit to account for the correlation between the dependent variables is indeed appropriate here.

\section{- $\quad$ Excluding de facto heads living with their husbands}

Table 5 compares the work responsibilities for de facto and de jure heads again, dropping de facto heads living with their husbands (in both migrant and non-migrant households).

\section{INSERT TABLE 5 HERE}

As can be seen, the results do not change by much when we drop de facto heads living with their husbands from the sample. The sign of the coefficient changes for the variables presence of adult male members in model 3 and interaction of caste and asset index for model 1. However, both these coefficients are not 
statistically significant. Also, the correlation coefficient for the unobservables in models 3 and 4 loses its statistical significance; however the Wald-statistic for testing the hypothesis that correlation coefficient between the unobservables in the three models $(2,3$, and 4$)$ equals zero is 28.39 , so we can reject the hypothesis of independence between the models.

\section{- Work responsibilities of de facto heads, migrant vs. non-migrant households}

In table 6, we present results for a sample that includes only de facto households, in order to examine any differences based on whether women belong to migrant households or not (defined as mig =1 if woman belongs to migrant household and 0 otherwise).

\section{INSERT TABLE 6 HERE}

When comparing work activities of de facto heads in migrant and non-migrant households, we see that de facto heads in migrant households are likely to have greater participation in self-employment in agriculture and lower participation in self-employment in non-agriculture and wage-employment - perhaps because they receive remittances from their husbands. Also, women may need to take up the family's agricultural work, when men leave. The difference in household work between de facto heads in migrant and non-migrant households is not statistically significant, as household work is mainly considered to be the primary responsibility of all women.

- Work responsibilities of de facto heads living with husband vs. not living with husband.

The analysis in Table 7 presents results comparing work responsibilities for de facto based on whether the female head is currently residing with her husband or not (defined as a binary variable with value 1 for women living with their husbands and 0 otherwise).

\section{INSERT TABLE 7 HERE}

Table 7 shows that among de facto heads, those living with their husbands are likely to spend less time in household work and in self-employment in agriculture, perhaps because their husbands help them out with some of these tasks. De facto heads living with their spouses are more likely to take on income generating activities either in wage-employment or self-employment in non-agriculture sector. This is consistent with our assumption that de facto heads living with their husbands are probably the primary earners of their family.

- Work responsibilities of de jure heads, widows vs. non-widows 
In this sample, we define widow_head as a binary variable with value 1 for widow heads and 0 for female heads who have either never been married or are separated or divorced). Table 8 presents results for the disaggregated de jure female heads.

INSERT TABLE 8 HERE

We do not find a statistically significant difference in the work activities of de jure heads based on whether they are widowed, separated, divorced, or have never been married. Economic status, measured using ownership of assets and land ownership, seems to be a key influence in women's activities.

De jure heads from wealthier families (higher asset index) are likely to have less domestic work and lower participation in self-employment in agriculture and wage-employment. However, they are more likely to be self-employed in non-agriculture - perhaps because they are able to invest in capital and skill training for selfemployment in non-agricultural sector (based on fieldwork - this is the most preferred form of employment for women). The lower participation of de jure heads in the other three activities could be because of their higher economic status that allows them to hire domestic help and reduces the necessity to take up wageemployment. De jure heads in households with higher land ownership, on the other hand, have more household work and greater participation in self-employment in agriculture, since they are more likely to be involved in animal rearing and agricultural work.

\section{Integrating quantitative and qualitative data}

Findings from the NLSS indicate overall trends in the types of activities de facto and de jure heads are likely to undertake. Qualitative data from fieldwork provide support to these overall findings and indicate the processes that determine women's work burdens and their participation in wage employment. Quantitative analysis indicates that de facto heads are, in general, likely to have more domestic work and greater participation in self-employment in agriculture. In migrant households in particular, de facto female heads take on additional domestic and agricultural activities in the absence of their husbands. At the same time, absent men may still be the primary providers for the family through remittances, so women may not be financially pressed to seek wage-employment and may choose to spend more time in domestic work, child care, and subsistence agricultural work. Interviews with de facto heads confirm that even though they are the everyday managers of their households, their (migrant) spouse may take decisions regarding their market participation. As Sapana Sapkota, a 22-year old migrant wife, whose husband had been away for two years, remarked: 
My husband doesn't like me working outside. Even if there is some agricultural work at a neighbor's field, he says that the earning from such work is low and that it is not worth going out to work for other people. He just doesn't like it [S. Sapkota, Chitwan].

Some evidence from India (Klasen and Pieters 2015) argues that women's participation in the workforce declines due to a combination of conservative attitudes towards women's work along with husbands' rising incomes. This phenomenon is observable in Nepal, where women themselves may choose not to participate in wage employment or self-employment in non-agriculture due to remittance incomes. The following statement from Sita Bartaula, a migrant wife who relied on remittances sent by her husband working as a driver in Qatar, confirms income effects from the husband's employment in remittance receiving migrant households.

It is not necessary for me to work. I receive remittances from my husband for our everyday expenses. [S. Bartaula, Chitwan].

Similarly, Pratima Chhetri, a 22-year old migrant wife explained:

I don't feel the need to work. We have enough income for me and my son here from the remittances my husband sends. [P. Chhetri, Rolpa].

Interviews indicated that low wages for women's work and cultural norms around married working women are deterrents for de facto heads' participation in wage employment. Barsha Singh, a migrant wife who had been working as a social mobilizer for the first three years of her marriage, gave up her job a year after her husband migrated due to pressures from her husband to invest more of her time in childcare and household work.

Before my husband migrated, I worked as a social mobilizer ... I made only about 5000 rupees a month from this job. After he migrated, he told me that the pay was too low and that he was earning enough for the family so I should focus on taking care of the kids. So, I quit my job. [B. Singh, Rolpa]

De facto female heads living with their husbands, on the other hand, are likely to spend somewhat lesser time in household work and agricultural self-employment, presumably because their spouses are helping them with these tasks. These de facto heads take up income generating activities either in wage-employment or self-employment in non-agriculture, as the likely primary earners of their households. There is thus some heterogeneity even within the category of de facto female heads of household.

De jure heads - many likely to be primary earners and maintainers of their households - have greater participation in self-employment in non-agriculture and in wage-employment. Preferences for paid work emerge despite low wages to women for such work due to the sheer necessity of providing for their families and the lack of other sources of income (such as remittances). In the Nepalese context, de jure heads 
frequently do not have access to productive assets such as land (which may explain their reduced likelihood of participating in self-employment in agriculture). While recent legal reform does confer some inheritance rights on daughters and wives, many de jure female heads do not exercise these rights for fear of losing other forms of everyday kin support (Rankin 2003; Ramnarain 2015). The remarks of de jure head Anju Thapa, the widow of a soldier killed in action during the conflict, are salient here:

My husband had a share of land in the village .... I did not ask for it because I did not want to displease (relatives). If I need some help in the future, they are the people who will come to our aid. [A. Thapa, Kathmandu]

Despite knowledge of their legal rights, Anju Thapa and other widows did not broach the issue of compensation for their husband's share of property with marital kin for fear of alienating them. In the absence of other forms of social security, maintaining cordial kin relations was a crucial survival strategy for de jure heads.

Other de jure heads were displaced forcibly from property, or were situated in an uncomfortable détente with marital kin, where land or property found no mention. Sarjani Saha, a 36-year old widow with two young children, stated:

My brothers-in-law did not want to give me or my children a share of the family property ... they threw me out. [S. Saha, Tanahu]

Similarly, Kamala Karki, an army widow who chose to remain in Kathmandu with her child described how relations stood with her marital relatives, who lived in an adjoining village to her parents (the same ward):

As long as I do not say anything about our share of the land, things will remain cordial. If something comes up (relating to the issue of land) when I do bring (son) to see his grandparents (her in-laws), my mother-in-law quickly changes the subject. My brother-in-law farms on the property and has his own family ... When my husband died, my mother advised me not to ask for the inheritance because they don't want any bad blood [K. Karki, Kathmandu]

De jure heads' lack of access to land - as illustrated by their narratives above - implies that they must take up market work in order to earn a living, adding support to quantitative findings.

Where de facto heads may be restricted from taking up market work by their husbands, in-laws or other family members, de jure heads likely face fewer restrictions to their everyday mobility due to the absence of male spouses in their households. Though de jure heads may face criticism for their participation in market work, the pressing need to provide for the family - especially young children - provides a justification for them to step into public spaces. Ruwanpura (2006) in Sri Lanka and Ramnarain (2016) in Nepal find, for instance, that even as de jure heads come under particular social scrutiny in South Asian contexts, they are also able to employ patriarchal discourses of being a 'good mother' to access wage employment and mobility in public spaces otherwise restricted to them. 
De jure heads are also less likely to perform domestic work or childcare. Ruwanpura (2006) observes, in the case of post-conflict Sri Lanka, that children were a crucial resource for female heads, with older sons taking up external employment and older daughters performing some of the housework. Qualitative data from Nepal also provide some indication that de jure (widow) heads coped with the intensification of their workdays upon taking up wage employment through utilizing the labor of other household members, particularly older children, although no gendered patterns were revealed.

\section{CONCLUSION}

This study provided a multi-method analysis of the work responsibilities and constraints faced by de facto and de jure female heads of household in post-conflict Nepal. Quantitative data from NLSS were supplemented with data and narratives collected through qualitative primary data to identify differences in the experiences of these two categories of female heads and processes explaining these differences. First, it shows that disaggregating the catch-all category of female-headed households provides additional insights into the specific challenges faced by each type of female head in their work responsibilities within and outside the household, rather than consign such households to a homogeneous, catch-all category. Second, such analysis destabilizes female headship as the face of poverty and complicates questions of agency and power. Indeed, we see that de facto heads, while not income poor due to remittance flows, still experience time constraints, reduced decision-making power, and increased work burdens in performing household reproductive and agricultural work. De jure heads, on the other hand, face greater constraints in access to resources such as property but are able to negotiate some entry into public spaces and market work. Finally, we see that even within the category of de facto FHHs, there is some variation depending upon the presence of the spouse (type of household or family living arrangements) and whether a female head is a primary earner or not.

Such disaggregation of female headship, while especially relevant for Nepal, may be of importance in other contexts as well, in identifying appropriate poverty alleviation or labor market inclusion programs for each type of female-headed household. De jure heads will benefit from stronger property rights, removal of structural barriers in women's access to work, and access to skills development training given their need driven participation in wage labor and in self-employment. On the other hand, measures of time poverty for de facto household heads would be a useful step in recognizing the non-income aspects of their marginalization, and in facilitating their agency.

\section{REFERENCES}


Acharya, Chakra P. and Roberto Leon-Gonzalez. 2012. "The Impact of Remittance on Poverty and Inequality: A Micro-Simulation Study for Nepal.” National Graduate Institute for Policy Studies, Discussion Paper: 11-26.

Acosta, Pablo. 2006. "Labor Supply, School Attendance, and Remittances from International Migration: The Case of El Salvador.” World Bank Policy Research Paper \#3903.

Adhikari, Jagannath and Mary Hobley. 2015. "Everyone is leaving. Who Will Sow Our Fields? The Livelihood Effects on Women of Male Migration from Khotang and Udaypur Districts Nepal to the Gulf Countries and Malaysia." Himalaya, The Journal of the Association for Nepal and Himalayan Studies, 35(1), Article 7.

Bennett, Lynn and Meena Acharya. 1983. "Women and the subsistence sector: Economic participation and household decision-making in Nepal.” World Bank Staff Working Papers No. 526, Washington, D.C.: The World Bank.

Brown, Barbara B. 1983. "The Impact of Male Labour Migration on Women in Botswana." African Affairs, 82 (38): 367-388.

Brück, Tilman, and Kati Schindler. "The impact of violent conflicts on households: What do we know and what should we know about war widows?” Oxford Development Studies 37, no. 3 (2009): 289-309.

Cappellari, Lorenzo and Stephen P. Jenkins. 2003. "Multivariate Probit Regression Using Simulated Maximum Likelihood.” The Stata Journal 3: 278-94.

Chant, Sylvia. 1997. Women-headed Households: Diversity and Dynamics in the Developing World, New York: St. Martin's Press.

Chant, Sylvia. 2003. Female household headship and the feminisation of poverty: facts, fictions and forward strategies. New Working Paper Series, Issue 9. Gender Institute, London School of Economics and Political Science.

Chant, Sylvia. 2004. "Dangerous Equations? How Female-headed Households Became the Poorest of the Poor: Causes, Consequences and Cautions.” IDS bulletin 35 (4): 19-26.

Chib, Siddhartha, and Edward Greenberg. 1998. "Analysis of multivariate probit models.” Biometrika 85 (2): 347-361.

Cohen, Jeffrey H., Rodriguez, Leila and Margaret Fox. 2008. "Gender and Migration in the Central Valleys of Oaxaca.” International Migration, 46(1).

Datta, Kavita, and Cathy McIlwaine. 2000. "Empowered leaders'? Perspectives on women heading households in Latin America and Southern Africa.” Gender \& Development 8(3): 40-49.

Fuwa, Nobuhiko. 2000. "The poverty and heterogeneity among female-headed households revisited: the case of Panama.”World Development 28(8): 1515-1542.

Galvin, Kathy Lee (2006), Forbidden Red: Widowhood in Urban Nepal, Washington State University Press. 
Handa, Sudhanshu. 1996. "Expenditure behavior and children's welfare: An analysis of female headed households in Jamaica.” Journal of development Economics 50(1): 165-187.

Hetler, Carol B. 1990. "Survival strategies, migration and household headship" in Leela Dube, and Rajni Palriwala, eds. Structures and strategies: women, work and family, pp. 175-199, New Delhi: Sage

Publications.

Horrell, Sara, and Pramila Krishnan. 2007. "Poverty and productivity in female-headed households in Zimbabwe.” The Journal of Development Studies 43 (8): 1351-1380.

Howell, Jayne. 2002. Of Servanthood and Self-Employment: Changing Patterns of Domestic Service in Southern Mexico. Urban Anthropology, 31 (3/4): 389-422.

Islam, Mahmuda. 1993. "Female-headed Households in Rural Bangladesh: A Survey" in Joan Mencher and Ann Okungwu, eds. Where Did All the Men Go? Boulder: Westview Press, p. 233-242.

Jetley, Surinder. 1987. "Impact of Male Migration on Rural Females." Economic and Political Weekly, 22(44), WS47-WS53.

Kasper, Heidi. 2005. "I am the Household Head Now! Gender Aspects of Out-Migration for Labour in Nepal.” Nepal Institute of Development Studies.

Kennedy, Eileen, and Pauline Peters. 1992. "Household food security and child nutrition: the interaction of income and gender of household head.” World development 20(8): 1077-1085.

Kennedy, Eileen, and Lawrence Haddad. 1994. "Are pre-schoolers from female-headed households less malnourished? A comparative analysis of results from Ghana and Kenya.” The Journal of Development Studies 30(3): 680-695.

Klasen, Stephan, and Janneke Pieters. 2015. "What explains the stagnation of female labor force participation in urban India?.” The World Bank Economic Review 29 (3): 449-478.

Kossoudji, Sherrie, and Eva Mueller. 1983. "The economic and demographic status of female-headed households in rural Botswana.” Economic Development and Cultural Change 31(4): 831-859.

Lingam, Lakshmi. 1994. "Women-Headed Households: Coping with Caste, Class and Gender Hierarchies.” Economic and Political Weekly, March 19, 699-704.

Lipton, Michael, 1980. "Migration from the Rural Areas of Poor Countries: The Impact on Rural Productivity and Income Distribution.” World Development 8(1): 1-24.

Lokshin, Michael, Bontch-Osmolovski, Mikhail and Elena Glinskaya. 2007. "Work-Related Migration and Poverty Reduction in Nepal.” World Bank Policy Research Paper No. 4231.

Lokshin, Michael and Elena Glinskaya. 2008. "The Effect of Male Migration for Work on Employment Patterns for Females in Nepal.” Policy Research Working Paper 4757, The World Bank, Development Research Group, Poverty Team. 
Maharjan, Amina, Bauer, Siegfried, and Beatrice Knerr. 2012. "Do Rural Women Who Stay Behind Benefit from Male Out-Migration? A Case Study in the Hills of Nepal.” Gender, Technology and Development, 16(1): 95-123.

Menon, Nidhiya, and Yana van der Meulen Rodgers. 2015. "War and women's work evidence from the conflict in Nepal." Journal of Conflict Resolution 59(1): 51-73.

Nepal Living Standards Survey (2010-11) (NLSS III), Central Bureau of Statistics - National Planning Commission Secretariat, Government of Nepal.

Newbury, Catharine and Hannah Baldwin. 2000. "Aftermath: Women in Post-Genocide Rwanda.” Working Paper 303, Center for Development Information and Evaluation, Washington DC: USAID.

Nowrojee, Binaifer. 1996. Shattered Lives: Sexual Violence during the Rwandan Genocide and its Aftermath, New York: Human Rights Watch.

Onyango, Adelheid, Katherine Tucker, and Thomas Eisemon. 1994. "Household headship and child nutrition: A case study in western Kenya.” Social Science \& Medicine 39(12): 1633-1639.

Ramnarain, Smita. 2016. "Unpacking Widow Headship and Agency in Post-Conflict Nepal.” Feminist Economics 22 (1): 80-105.

Rankin, Katharine N. 2003. "Cultures of economies: gender and socio-spatial change in Nepal.” Gender, Place and Culture: A Journal of Feminist Geography 10 (2): 111-129.

Rosenhouse, Sandra Persson 1989. "Identifying the poor: Is headship a useful concept?” Living Standard Measurement Study No. 58, Washington DC: World Bank.

Ruwanpura, Kanchana N. and Jane Humphries. 2004. "Mundane heroines: Conflict, ethnicity, gender, and female headship in eastern Sri Lanka.” Feminist Economics 10(2): 173-205.

Ruwanpura, Kanchana. 2006. Matrilineal Communities, Patriarchal Realities: A Feminist Nirvana Uncovered, Ann Arbor: University of Michigan Press.

Sadiqui, Fatima \& Moha Ennaji. 2004. "The Impact of Male Migration from Morocco to Europe on Women: A Gender Approach.” Finisterra, XXXIX, 77, 59-76

Turshen, Meredith. 2001. 'The Political Economy of Rape: An Analysis of Systematic Rape and Sexual Abuse of Women during Armed Conflict in Africa,' in Caroline Moser and Fiona Clark, eds. Victims, Perpetrators or Actors: Gender, Armed Conflict and Political Violence, London and New York: Zed Books, p. 55-68.

Varley, Ann. 1996. "Women heading households: Some more equal than others?” World Development 24 (3): 505-520.

Yadav, Punam. 2016. 'White Sari-Transforming Widowhood in Nepal.' Gender, Technology and Development 20 (1): 1-24.

Youssef, Nadia and Carol B. Hetler. 1981. Women-Headed Households and Rural Poverty: What do We Know? Washington, D.C.: International Center for Research on Women. 
Youssef, Nadia and Carol B. Hetler. 1983. "Establishing the Economic Condition of Women-headed Households in the Third World: A New Approach" in Mayra Buvinic, Margaret A. Lycette, and William P. McGreevey, eds. Women and Poverty in the Third World, pp. 216-43. London: Johns Hopkins University Press.

Young, Gary, Emiliano Valdez, and Robert Kohn. 2009. "Multivariate Probit Models for Conditional ClaimTypes.” Insurance: Mathematics and Economics. 44(2), 214 - 228.

Zuckerman, Elaine, and Marcia Greenberg. 2004. "The gender dimensions of post-conflict reconstruction: an analytical framework for policymakers.” Gender \& Development 12 (3): 70-82.

\section{ENDNOTES}

'Seddon et al. (1998) argue that male migration and Nepal's remittance economy were well-established before the conflict began in 1996, although it is conceivable that the conflict accelerated rates of departure from affected regions (see Menon and Rodgers 2015).

${ }^{2}$ In the survey, head of the household is defined as the person in the household acknowledged as head by other household members.

3 The NLSS does not identify spouse's cause of death and includes all widows. Primary interview data collected through fieldwork pertain, however, only to conflict widows.

${ }^{4}$ Around 4 percent of Nepalese women are in a polygamous relationship (DHS 2011). While a man found to be practicing polygamy may be fined, the law does not invalidate the second marriage and there is cultural acceptance of polygamy.

${ }^{5}$ Development and gender inequality indices are based on the report 'Districts of Nepal: Indicators of Development, Update 2003', Central Bureau of Statistics, Government of Nepal and the International Genter for Integrated Mountain Development (ICIMOD).

${ }^{6}$ The asset index is an equally weighted index based on five household characteristics (wall material, source of drinking water, type of toilet, source of light, cooking fuel) and ownership of eight assets (camera, television, computer, heater, refrigerator, telephone, motorcycle and fan). The five household characteristics are assigned values 0 to 2, with higher value representing better standard of living and each of the eight variables for asset ownership are assigned 1 for owning the asset and 0 otherwise.

${ }^{7}$ We tested if receipt of remittances affected women's work responsibilities and found that the variable was not statistically significant in any of the models. 
Table 1: Descriptive Statistics for De Jure Heads

\begin{tabular}{|c|c|c|c|}
\hline & & $\begin{array}{l}\text { Widow heads } \\
(\mathrm{N}=387)\end{array}$ & $\begin{array}{l}\text { Never married/ } \\
\text { Separated/ Divorced } \\
(\mathrm{N}=132)\end{array}$ \\
\hline \multirow[t]{2}{*}{ Age } & Mean & 55.1 & 38.7 \\
\hline & Std. Deviation & 12.5 & 15.9 \\
\hline \multirow[t]{2}{*}{ Years of Education } & Mean & 1.0 & 5.5 \\
\hline & Std. Deviation & 2.9 & 6.7 \\
\hline \multirow[t]{2}{*}{ Asset Index } & Mean & 0.3 & 0.4 \\
\hline & Std. Deviation & 0.3 & 0.2 \\
\hline \multirow[t]{2}{*}{ Number of dependent members } & Mean & 1.7 & 0.8 \\
\hline & Std. Deviation & 1.5 & 1.1 \\
\hline \multicolumn{2}{|c|}{ Percentage of households with adult male member } & $43.4 \%$ & $29.6 \%$ \\
\hline \multicolumn{2}{|c|}{ Percentage of households with other adult female members } & $39.8 \%$ & $35.6 \%$ \\
\hline \multicolumn{2}{|c|}{ Percentage of households receiving remittances } & $63.1 \%$ & $67.4 \%$ \\
\hline \multirow[t]{2}{*}{ Land ownership } & Mean & 0.4 & 0.1 \\
\hline & Std. Deviation & 0.5 & 0.3 \\
\hline \multirow[t]{2}{*}{ Caste } & High caste & $49.4 \%$ & $53.8 \%$ \\
\hline & Low caste & $50.6 \%$ & $46.2 \%$ \\
\hline \multirow[t]{2}{*}{ Location } & Urban & $35.1 \%$ & $53.0 \%$ \\
\hline & Rural & $64.9 \%$ & $47.0 \%$ \\
\hline \multirow[t]{3}{*}{ Ecological Belt } & Mountain Belt & $7.0 \%$ & $8.3 \%$ \\
\hline & Hill Belt & $59.7 \%$ & $70.5 \%$ \\
\hline & Terai Belt & $33.3 \%$ & $21.2 \%$ \\
\hline
\end{tabular}

Table 2: Descriptive Statistics for De Facto heads

\begin{tabular}{|c|c|c|c|c|c|}
\hline & & $\begin{array}{l}\text { Belong to } \\
\text { migrant } \\
\text { household } \\
(\mathrm{N}=855)\end{array}$ & $\begin{array}{l}\text { Belong to non- } \\
\text { migrant household } \\
(\mathrm{N}=225)\end{array}$ & $\begin{array}{l}\text { Living with } \\
\text { their husbands } \\
(\mathrm{N}=235)\end{array}$ & $\begin{array}{l}\text { Living without } \\
\text { their husbands } \\
(\mathrm{N}=845)\end{array}$ \\
\hline \multirow[t]{2}{*}{ Age } & Mean & 35.7 & 38.7 & 39.9 & 35.4 \\
\hline & Std. Deviation & 9.2 & 11.5 & 11.5 & 9.0 \\
\hline \multirow{2}{*}{$\begin{array}{l}\text { Years of } \\
\text { Education }\end{array}$} & Mean & 3.3 & 3.9 & 3.9 & 3.3 \\
\hline & Std. Deviation & 4.3 & 5.3 & 5.3 & 4.3 \\
\hline \multirow{2}{*}{$\begin{array}{l}\text { Asset } \\
\text { Index }\end{array}$} & Mean & 0.3 & 0.4 & 0.4 & 0.3 \\
\hline & Std. Deviation & 0.2 & 0.2 & 0.2 & 0.2 \\
\hline \multirow{2}{*}{$\begin{array}{l}\text { Number of } \\
\text { dependent } \\
\text { members }\end{array}$} & Mean & 2.2 & 1.9 & 2.1 & 2.2 \\
\hline & Std. Deviation & 1.3 & 1.3 & 1.4 & 1.3 \\
\hline \multicolumn{2}{|c|}{$\begin{array}{l}\text { Percentage of households with } \\
\text { adult male member (16-65 yrs.) }\end{array}$} & $25.2 \%$ & $76.4 \%$ & $88.5 \%$ & $21.2 \%$ \\
\hline \multicolumn{2}{|c|}{$\begin{array}{l}\text { Percentage of households with } \\
\text { other adult female members } \\
\text { (16-65 yrs.) }\end{array}$} & $27.6 \%$ & $30.2 \%$ & $34.0 \%$ & $26.5 \%$ \\
\hline \multicolumn{2}{|c|}{$\begin{array}{l}\text { Percentage of households } \\
\text { receiving remittances }\end{array}$} & $93.6 \%$ & $41.8 \%$ & $48.9 \%$ & $92.2 \%$ \\
\hline
\end{tabular}




\begin{tabular}{|l|l|l|l|l|l|}
\hline \multirow{2}{*}{$\begin{array}{l}\text { Land } \\
\text { ownership }\end{array}$} & Mean & 0.3 & 0.3 & 0.4 & 0.3 \\
\cline { 2 - 6 } & Std. Deviation & 0.5 & 1.4 & 1.3 & 0.5 \\
\hline \multirow{2}{*}{ Caste } & High caste & $41.9 \%$ & $47.1 \%$ & $44.7 \%$ & $42.6 \%$ \\
\cline { 2 - 6 } & Low caste & $58.1 \%$ & $52.9 \%$ & $55.3 \%$ & $57.4 \%$ \\
\hline \multirow{2}{*}{ Location } & Urban & $27.3 \%$ & $41.8 \%$ & $41.3 \%$ & $27.2 \%$ \\
\cline { 2 - 6 } & Rural & $72.7 \%$ & $58.2 \%$ & $58.7 \%$ & $72.8 \%$ \\
\hline \multirow{2}{*}{$\begin{array}{l}\text { Ecological } \\
\text { Belt }\end{array}$} & Mountain Belt & $5.9 \%$ & $4.9 \%$ & $5.1 \%$ & $5.8 \%$ \\
\cline { 2 - 6 } & Hill Belt & $50.3 \%$ & $64.0 \%$ & $61.7 \%$ & $50.8 \%$ \\
\cline { 2 - 6 } & Terai Belt & $43.8 \%$ & $31.1 \%$ & $33.2 \%$ & $43.4 \%$ \\
\hline
\end{tabular}

Table 3: Descriptive Statistics for Independent Variables

\begin{tabular}{|c|c|c|c|c|}
\hline & & $\begin{array}{l}\text { De jure heads } \\
(\mathrm{N}=519)\end{array}$ & $\begin{array}{l}\text { De facto } \\
\text { heads } \\
(\mathrm{N}=1,080)\end{array}$ & $\begin{array}{l}\text { All female heads } \\
(\mathrm{N}=1,599)\end{array}$ \\
\hline \multirow[t]{2}{*}{ Age } & Mean & 50.9 & 36.3 & 41.1 \\
\hline & Std. Deviation & 15.2 & 9.8 & 13.7 \\
\hline \multirow[t]{2}{*}{ Years of Education } & Mean & 2.2 & 3.4 & 3.0 \\
\hline & Std. Deviation & 4.6 & 4.5 & 4.6 \\
\hline \multirow[t]{2}{*}{ Asset Index } & Mean & 0.3 & 0.3 & 0.3 \\
\hline & Std. Deviation & 0.2 & 0.2 & 0.2 \\
\hline \multirow{2}{*}{$\begin{array}{l}\text { Number of dependent } \\
\text { members }\end{array}$} & Mean & 1.5 & 2.2 & 1.9 \\
\hline & Std. Deviation & 1.4 & 1.3 & 1.4 \\
\hline \multicolumn{2}{|c|}{$\begin{array}{l}\text { Percentage of households with adult male } \\
\text { member }\end{array}$} & $39.9 \%$ & $35.8 \%$ & $37.2 \%$ \\
\hline \multicolumn{2}{|c|}{$\begin{array}{l}\text { Percentage of households with other adult } \\
\text { female members }\end{array}$} & $38.7 \%$ & $28.2 \%$ & $31.6 \%$ \\
\hline \multicolumn{2}{|c|}{$\begin{array}{l}\text { Percentage of households receiving } \\
\text { remittances }\end{array}$} & $64.2 \%$ & $82.8 \%$ & $76.7 \%$ \\
\hline \multirow[t]{2}{*}{ Land ownership } & Mean & 0.3 & 0.3 & 0.3 \\
\hline & Std. Deviation & 0.5 & 0.8 & 0.7 \\
\hline \multirow[t]{2}{*}{ Caste } & High caste & $50.5 \%$ & $43.1 \%$ & $45.5 \%$ \\
\hline & Low caste & $49.5 \%$ & $56.9 \%$ & $54.5 \%$ \\
\hline \multirow[t]{2}{*}{ Location } & Urban & $39.7 \%$ & $30.3 \%$ & $33.3 \%$ \\
\hline & Rural & $60.3 \%$ & $69.7 \%$ & $66.7 \%$ \\
\hline \multirow[t]{3}{*}{ Ecological Belt } & Mountain Belt & $7.3 \%$ & $5.7 \%$ & $6.2 \%$ \\
\hline & Hill Belt & $62.4 \%$ & $53.2 \%$ & $56.2 \%$ \\
\hline & Terai Belt & $30.3 \%$ & $41.1 \%$ & $37.6 \%$ \\
\hline
\end{tabular}

Table 4: Comparison of work responsibilities for all de facto and de jure FHHs

\begin{tabular}{|l|l|l|l|l|}
\hline & $\begin{array}{l}\text { Model 1: } \\
\text { hh_work }\end{array}$ & $\begin{array}{l}\text { Model 2: } \\
\text { s_ag }\end{array}$ & $\begin{array}{l}\text { Model 3: } \\
\text { s_n_ag }\end{array}$ & $\begin{array}{l}\text { Model 4: } \\
\text { wage }\end{array}$ \\
\hline de facto & $2.967^{* * *}$ & $0.234^{*}$ & $-0.306^{* *}$ & $-0.435^{* * *}$ \\
& $(0.837)$ & $(0.097)$ & $(0.112)$ & $(0.108)$ \\
\hline
\end{tabular}




\begin{tabular}{|c|c|c|c|c|}
\hline age & $\begin{array}{l}0.300 \\
(0.217)\end{array}$ & $\begin{array}{l}0.040^{*} \\
(0.018)\end{array}$ & $\begin{array}{l}0.076^{* *} \\
(0.025)\end{array}$ & $\begin{array}{l}0.110^{* * *} \\
(0.026)\end{array}$ \\
\hline age-squared & $\begin{array}{l}-0.00732^{* *} \\
(0.00227)\end{array}$ & $\begin{array}{l}-0.0004^{*} \\
(0.00019)\end{array}$ & $\begin{array}{l}-0.0009^{* * *} \\
(0.0002)\end{array}$ & $\begin{array}{l}-0.001 \text { ** * } \\
(0.0003)\end{array}$ \\
\hline Years of education & $\begin{array}{l}0.0925 \\
(0.215) \\
\end{array}$ & $\begin{array}{l}-0.011 \\
(0.017) \\
\end{array}$ & $\begin{array}{l}0.019 \\
(0.017) \\
\end{array}$ & $\begin{array}{l}0.026 \\
(0.017) \\
\end{array}$ \\
\hline Wage-employed & $\begin{array}{l}-7.065^{* * *} \\
(1.149) \\
\end{array}$ & & & \\
\hline Presence of adult female members & $\begin{array}{l}-5.609^{* * *} \\
(1.060)\end{array}$ & $\begin{array}{l}-0.123 \\
(0.084)\end{array}$ & & \\
\hline Number of dependent members & $\begin{array}{l}1.510^{* * *} \\
(0.360)\end{array}$ & $\begin{array}{l}0.041 \\
(0.028)\end{array}$ & $\begin{array}{l}0.014 \\
(0.034)\end{array}$ & $\begin{array}{l}-0.027 \\
(0.034)\end{array}$ \\
\hline Presence of adult male members & & & $\begin{array}{l}0.145 \\
(0.093) \\
\end{array}$ & $\begin{array}{l}-0.033 \\
(0.093) \\
\end{array}$ \\
\hline Asset Index & $\begin{array}{l}-22.95^{* * *} \\
(3.780)\end{array}$ & $\begin{array}{l}-0.873^{* *} \\
(0.322) \\
\end{array}$ & $\begin{array}{l}0.984^{* *} \\
(0.338) \\
\end{array}$ & $\begin{array}{l}-0.543 \\
(0.341) \\
\end{array}$ \\
\hline Land Ownership & $\begin{array}{l}1.543 \\
(0.904)\end{array}$ & $\begin{array}{l}0.330^{* * *} \\
(0.068)\end{array}$ & $\begin{array}{l}-0.683^{* * *} \\
(0.155)\end{array}$ & $\begin{array}{l}-0.147 \\
(0.079)\end{array}$ \\
\hline High caste & $\begin{array}{l}.340 \\
(1.868)\end{array}$ & $\begin{array}{l}0.152 \\
(0.139)\end{array}$ & $\begin{array}{l}-0.190 \\
(0.184)\end{array}$ & $\begin{array}{l}-0.573^{* *} \\
(0.173)\end{array}$ \\
\hline Caste_Education & $\begin{array}{l}0.0521 \\
(0.255) \\
\end{array}$ & $\begin{array}{l}0.026 \\
(0.020) \\
\end{array}$ & $\begin{array}{l}-0.030 \\
(0.022) \\
\end{array}$ & $\begin{array}{l}0.018 \\
(0.021) \\
\end{array}$ \\
\hline Caste_Asset Index & $\begin{array}{l}-1.072 \\
(4.721) \\
\end{array}$ & $\begin{array}{l}-0.248 \\
(0.441) \\
\end{array}$ & $\begin{array}{l}0.206 \\
(0.488) \\
\end{array}$ & $\begin{array}{l}0.503 \\
(0.487) \\
\end{array}$ \\
\hline Location & $\begin{array}{l}8.468^{* * *} \\
(1.292) \\
\end{array}$ & $\begin{array}{l}0.598^{* * *} \\
(0.103) \\
\end{array}$ & $\begin{array}{l}-(0.099 \\
(0.111) \\
\end{array}$ & $\begin{array}{l}-\left(0.463^{* * *}\right. \\
(0.109)\end{array}$ \\
\hline Mountain belt & $\begin{array}{l}-1.973 \\
(2.116)\end{array}$ & $\begin{array}{l}0.438^{* *} \\
(0.147)\end{array}$ & $\begin{array}{l}0.210 \\
(0.180)\end{array}$ & $\begin{array}{l}0.210 \\
(0.181)\end{array}$ \\
\hline Hill belt & $\begin{array}{l}2.735^{* *} \\
(1.027) \\
\end{array}$ & $\begin{array}{l}0.536^{* * *} \\
(0.079)\end{array}$ & $\begin{array}{l}0.054 \\
(0.093) \\
\end{array}$ & $\begin{array}{l}0.175 \\
(0.093) \\
\end{array}$ \\
\hline Constant term & $\begin{array}{l}37.01^{* * *} \\
(5.230) \\
\end{array}$ & $\begin{array}{l}-2.071^{* * *} \\
(0.437)\end{array}$ & $\begin{array}{l}-2.466^{* * *} \\
(0.574)\end{array}$ & $\begin{array}{l}-2.04^{* * *} \\
(0.561) \\
\end{array}$ \\
\hline $\mathrm{N}$ & 1598 & 1390 & 1390 & 1390 \\
\hline R-squared & 0.270 & & & \\
\hline Rho32 & & \multicolumn{3}{|l|}{$\begin{array}{l}-0.122^{*} \\
(0.0551)\end{array}$} \\
\hline Rho42 & & \multicolumn{3}{|l|}{$\begin{array}{l}-0.111^{*} \\
(.055)\end{array}$} \\
\hline Rho43 & & \multicolumn{3}{|l|}{$\begin{array}{l}-0.328^{* * *} \\
(0.0550)\end{array}$} \\
\hline $\begin{array}{l}\text { Likelihood Ratio Test for } \\
\text { rho } 32=\operatorname{rho} 42=\operatorname{rho} 43=0\end{array}$ & & \multicolumn{3}{|c|}{$\begin{array}{l}\text { Chi } 2(3)=43.335 \\
\text { Prob }>\text { chi } 2=0.000\end{array}$} \\
\hline
\end{tabular}

Standard errors in parenthesis.

- $\mathrm{p}<0.05,{ }^{* *} \mathrm{p}<0.01,{ }^{* * *} \mathrm{p}<0.001$ 
Table 5: Comparison of work responsibilities of de facto and de jure FHHs, excluding de facto heads living with their husbands

\begin{tabular}{|c|c|c|c|c|}
\hline & $\begin{array}{l}\text { Model 1: } \\
\text { hh_work }\end{array}$ & $\begin{array}{l}\text { Model 2: } \\
\text { s_ag }\end{array}$ & $\begin{array}{l}\text { Model 3: } \\
\text { s_n_ag }\end{array}$ & $\begin{array}{l}\text { Model 4: } \\
\text { wage }\end{array}$ \\
\hline de facto & $\begin{array}{l}7.012^{* * *} \\
(1.257)\end{array}$ & $\begin{array}{l}0.237^{*} \\
(0.104)\end{array}$ & $\begin{array}{l}-0.451^{* * *} \\
(0.123)\end{array}$ & $\begin{array}{l}-\left(0.522^{* * *}\right. \\
(0.117)\end{array}$ \\
\hline age & $\begin{array}{l}0.330 \\
(0.220)\end{array}$ & $\begin{array}{l}0.0383 \\
(0.0197)\end{array}$ & $\begin{array}{l}0.07135^{* *} \\
(0.0270)\end{array}$ & $\begin{array}{l}0.103^{* * *} \\
(0.0284)\end{array}$ \\
\hline age-squared & $\begin{array}{l}-\left(0.00709^{* *}\right. \\
(0.00226)\end{array}$ & $\begin{array}{l}-\left(0.00042^{*}\right. \\
(0.000214)\end{array}$ & $\begin{array}{l}-0.000839^{* *} \\
(0.000297)\end{array}$ & $\begin{array}{l}-0.00140 \text { *** } \\
(0.000335)\end{array}$ \\
\hline Years of education & $\begin{array}{l}0.0728 \\
(0.223)\end{array}$ & $\begin{array}{l}-0.00736 \\
(0.0181)\end{array}$ & $\begin{array}{l}0.0231 \\
(0.0197)\end{array}$ & $\begin{array}{l}0.0294 \\
(0.0186)\end{array}$ \\
\hline Wage-employed & $\begin{array}{l}-6.640^{* * *} \\
(1.227)\end{array}$ & & & \\
\hline Presence of adult female members & $\begin{array}{l}-4.883^{* * *} \\
(1.136)\end{array}$ & $\begin{array}{l}-0.126 \\
(0.091)\end{array}$ & & \\
\hline Number of dependent members & $\begin{array}{l}1.068^{* *} \\
(0.393)\end{array}$ & $\begin{array}{l}0.0395 \\
(0.0305)\end{array}$ & $\begin{array}{l}0.0365 \\
(0.0385)\end{array}$ & $\begin{array}{l}-0.0548 \\
(0.0383)\end{array}$ \\
\hline Presence of adult male members & & & $\begin{array}{l}-0.0572 \\
(0.115)\end{array}$ & $\begin{array}{l}-0.1657 \\
(0.116)\end{array}$ \\
\hline Asset Index & $\begin{array}{l}-23.56^{* * *} \\
(3.908)\end{array}$ & $\begin{array}{l}-0.774 \\
\left(0.349^{*}\right.\end{array}$ & $\begin{array}{l}0.899^{*} \\
(0.382) \\
\end{array}$ & $\begin{array}{l}-0.585 \\
(0.384) \\
\end{array}$ \\
\hline Land Ownership & $\begin{array}{l}3.117^{* *} \\
(1.149)\end{array}$ & $\begin{array}{l}0.311^{* * *} \\
(0.072)\end{array}$ & $\begin{array}{l}-0.677^{* * *} \\
(0.1375\end{array}$ & $\begin{array}{l}-0.0714 \\
(0.0841)\end{array}$ \\
\hline High caste & $\begin{array}{l}0.861 \\
(1.946)\end{array}$ & $\begin{array}{l}0.178 \\
(0.151)\end{array}$ & $\begin{array}{l}-0.1771 \\
(0.204)\end{array}$ & $\begin{array}{l}-0.578^{* *} \\
(0.1947)\end{array}$ \\
\hline Caste_Education & $\begin{array}{l}0.0658 \\
(0.265)\end{array}$ & $\begin{array}{l}0.023 \\
(0.022)\end{array}$ & $\begin{array}{l}-0.0261 \\
(0.0249)\end{array}$ & $\begin{array}{l}0.0112 \\
(0.0243)\end{array}$ \\
\hline Caste_Asset Index & $\begin{array}{l}3.348 \\
(4.941)\end{array}$ & $\begin{array}{l}-0.354 \\
(483) \\
\end{array}$ & $\begin{array}{l}0.349 \\
(0.554) \\
\end{array}$ & $\begin{array}{l}0.280 \\
(0.557)\end{array}$ \\
\hline Location & $\begin{array}{l}8.347^{* * *} \\
(1.380)\end{array}$ & $\begin{array}{l}0.505^{* *} \\
(0.111)\end{array}$ & $\begin{array}{l}-0.025 \\
(0.125)\end{array}$ & $\begin{array}{l}-0.474^{* * *} \\
(0.125)\end{array}$ \\
\hline Mountain belt & $\begin{array}{l}-2.408 \\
(2.265)\end{array}$ & $\begin{array}{l}0.469^{* *} \\
(0.156)\end{array}$ & $\begin{array}{l}0.331 \\
(0.192)\end{array}$ & $\begin{array}{l}0.127 \\
(0.198)\end{array}$ \\
\hline Hill belt & $\begin{array}{l}3.074^{* *} \\
(1.100)\end{array}$ & $\begin{array}{l}0.549^{* * *} \\
(0.0859)\end{array}$ & $\begin{array}{l}0.115 \\
(0.105)\end{array}$ & $\begin{array}{l}0.202^{*} \\
(0.1025)\end{array}$ \\
\hline Constant term & $\begin{array}{l}33.45^{* * *} \\
(5.578)\end{array}$ & $\begin{array}{l}-1.938^{* * *} \\
(0.469)\end{array}$ & $\begin{array}{l}-2.435^{* * *} \\
(0.631)\end{array}$ & $\begin{array}{l}-1.740^{* *} \\
(0.602)\end{array}$ \\
\hline $\mathrm{N}$ & 1363 & \multicolumn{3}{|l|}{1182} \\
\hline R-squared/ Pseudo R- squared & 0.287 & & & \\
\hline Rho32 & & \multicolumn{3}{|l|}{$\begin{array}{l}-0.122^{*} \\
(0.0603)\end{array}$} \\
\hline Rho42 & & \multicolumn{3}{|l|}{$\begin{array}{l}-0.104 \\
(.058)\end{array}$} \\
\hline Rho43 & & \multicolumn{3}{|l|}{$\begin{array}{l}-0.294^{* * *} \\
(0.0651)\end{array}$} \\
\hline
\end{tabular}




\begin{tabular}{|l|l|}
\hline $\begin{array}{l}\text { Likelihood Ratio Test for } \\
\text { rho32=rho42=rho43=0 }\end{array}$ & $\begin{array}{l}\text { Chi2 }(3)=28.393 \\
\text { Prob>chi2 }=0.000\end{array}$ \\
\hline
\end{tabular}

Standard errors in parenthesis.

${ }^{*} \mathrm{p}<0.05,{ }^{* *} \mathrm{p}<0.01,{ }^{* * *} \mathrm{p}<0.001$

Table 6: Work responsibilities of de facto FHHs, migrant vs. non-migrant (dropping de jure heads)

\begin{tabular}{|c|c|c|c|c|}
\hline & $\begin{array}{l}\text { Model 1: } \\
\text { hh_work }\end{array}$ & $\begin{array}{l}\text { Model 2: } \\
\text { s_ag }\end{array}$ & $\begin{array}{l}\text { Model 3: } \\
\text { s_n_ag }\end{array}$ & $\begin{array}{l}\text { Model 4: } \\
\text { wage }\end{array}$ \\
\hline Belongs to migrant household & $\begin{array}{l}2.808 \\
(1.610)\end{array}$ & $\begin{array}{l}0.240^{*} \\
(0.113)\end{array}$ & $\begin{array}{l}-0.360^{*} \\
(0.142)\end{array}$ & $\begin{array}{l}-\left(0.383^{* *}\right. \\
(0.139)\end{array}$ \\
\hline age & $\begin{array}{l}-0.847^{*} \\
(0.389)\end{array}$ & $\begin{array}{l}0.0370 \\
(0.0255)\end{array}$ & $\begin{array}{l}0.07742 \\
(0.0408)\end{array}$ & $\begin{array}{l}0.127 * * \\
(0.0415)\end{array}$ \\
\hline age-squared & $\begin{array}{l}0.00570 \\
(0.00467)\end{array}$ & $\begin{array}{l}-0.000369 \\
(0.000301)\end{array}$ & $\begin{array}{l}-0.001007 \\
(0.000516)\end{array}$ & $\begin{array}{l}-0.00158^{* *} \\
(0.000531)\end{array}$ \\
\hline Years of education & $\begin{array}{l}0.151 \\
(0.253)\end{array}$ & $\begin{array}{l}0.00371 \\
(0.0191)\end{array}$ & $\begin{array}{l}0.01811 \\
(0.0206)\end{array}$ & $\begin{array}{l}0.0070 \\
(0.0201)\end{array}$ \\
\hline Wage-employed & $\begin{array}{l}-6.846^{* * *} \\
(1.370)\end{array}$ & & & \\
\hline Presence of adult female members & $\begin{array}{l}-5.113^{* * *} \\
(1.356)\end{array}$ & $\begin{array}{l}-0.058 \\
(0.103)\end{array}$ & & \\
\hline Number of dependent members & $\begin{array}{l}1.636^{* * *} \\
(0.441)\end{array}$ & $\begin{array}{l}0.0227 \\
(0.0338)\end{array}$ & $\begin{array}{l}-0.0389 \\
(0.0434)\end{array}$ & $\begin{array}{l}-0.0764 \\
(0.0427)\end{array}$ \\
\hline Presence of adult male members & & & $\begin{array}{l}0.0616 \\
(0.132)\end{array}$ & $\begin{array}{l}-0.154 \\
(0.128)\end{array}$ \\
\hline Asset Index & $\begin{array}{l}-25.99^{* * *} \\
(4.829)\end{array}$ & $\begin{array}{l}-1.014^{* *} \\
(0.387)\end{array}$ & $\begin{array}{l}1.075^{*} \\
(0.423)\end{array}$ & $\begin{array}{l}-0.104 \\
(0.417)\end{array}$ \\
\hline Land Ownership & $\begin{array}{l}1.020 \\
(0.666) \\
\end{array}$ & $\begin{array}{l}0.281^{* * *} \\
(0.0766)\end{array}$ & $\begin{array}{l}-\left(0.5306^{* *}\right. \\
(0.188)\end{array}$ & $\begin{array}{l}-0.0708 \\
(0.165) \\
\end{array}$ \\
\hline High caste & $\begin{array}{l}1.252 \\
(2.420)\end{array}$ & $\begin{array}{l}0.0498 \\
(0.1724)\end{array}$ & $\begin{array}{l}-0.359 \\
(0.244)\end{array}$ & $\begin{array}{l}-0.595^{* *} \\
(0.2179)\end{array}$ \\
\hline Caste_Education & $\begin{array}{l}0.456 \\
(0.329)\end{array}$ & $\begin{array}{l}0.023 \\
(0.024)\end{array}$ & $\begin{array}{l}-0.015 \\
(0.0276)\end{array}$ & $\begin{array}{l}0.0418 \\
(0.0270)\end{array}$ \\
\hline Caste_Asset Index & $\begin{array}{l}-1.957 \\
(6.419)\end{array}$ & $\begin{array}{l}-0.0251 \\
(.540)\end{array}$ & $\begin{array}{l}0.252 \\
(0.633)\end{array}$ & $\begin{array}{l}0.1917 \\
(0.609)\end{array}$ \\
\hline Location & $\begin{array}{l}7.183^{* * *} \\
(1.575) \\
\end{array}$ & $\begin{array}{l}0.635^{* * *} \\
(0.124)\end{array}$ & $\begin{array}{l}-0.211 \\
(0.1436 \\
\end{array}$ & $\begin{array}{c}-0.302^{*} \\
(0.133) \\
\end{array}$ \\
\hline Mountain belt & $\begin{array}{l}-3.831 \\
(2.664) \\
\end{array}$ & $\begin{array}{l}0.598^{* *} \\
(0.182) \\
\end{array}$ & $\begin{array}{l}0.194^{*} \\
(0.242)\end{array}$ & $\begin{array}{l}0.480^{*} \\
(0.213)\end{array}$ \\
\hline Hill belt & $\begin{array}{l}3.316^{* *} \\
(1.235)\end{array}$ & $\begin{array}{l}0.592^{* * *} \\
(0.094)\end{array}$ & $\begin{array}{l}0.112 \\
(0.114)\end{array}$ & $\begin{array}{l}0.222^{*} \\
(0.112)\end{array}$ \\
\hline Constant term & $\begin{array}{l}63.28^{* * *} \\
(8.004)\end{array}$ & $\begin{array}{l}-2.014^{* * *} \\
(0.557)\end{array}$ & $\begin{array}{l}-2.245^{* *} \\
(0.807)\end{array}$ & $\begin{array}{l}-2.729^{* *} \\
(0.800)\end{array}$ \\
\hline $\mathrm{N}$ & 1079 & \multicolumn{3}{|l|}{966} \\
\hline R-squared/ Pseudo R-squared & 0.236 & & & \\
\hline Rho32 & & \multicolumn{3}{|l|}{$-0.162^{*}$} \\
\hline
\end{tabular}




\begin{tabular}{|l|l|}
\hline & \\
\hline Rho42 & $(0.0683)$ \\
\hline Rho43 & -0.0844 \\
& $(0.0629)$ \\
\hline $\begin{array}{l}\text { Likelihood Ratio Test for } \\
\text { rho32=rho42=rho43=0 }\end{array}$ & $-0.294^{* * *}$ \\
$(0.0726)$ \\
\hline
\end{tabular}

Standard errors in parenthesis.

${ }^{*} \mathrm{p}<0.05,{ }^{* *} \mathrm{p}<0.01,{ }^{* * *} \mathrm{p}<0.001$

Table 7: Work responsibilities of de facto heads living with husband vs. not living with husband.

\begin{tabular}{|c|c|c|c|c|}
\hline & $\begin{array}{l}\text { Model 1: } \\
\text { hh_work }\end{array}$ & $\begin{array}{l}\text { Model 2: } \\
\text { s_ag }\end{array}$ & $\begin{array}{l}\text { Model 3: } \\
\text { s_n_ag }\end{array}$ & $\begin{array}{l}\text { Model 4: } \\
\text { wage }\end{array}$ \\
\hline Live with husband & $\begin{array}{l}-1.249 \\
(1.562)\end{array}$ & $\begin{array}{l}-0.155 \\
(0.111)\end{array}$ & $\begin{array}{l}0.435^{* *} \\
(0.156)\end{array}$ & $\begin{array}{l}0.307 \\
(0.158)\end{array}$ \\
\hline age & $\begin{array}{c}-\left(0.829^{*}\right. \\
(0.388)\end{array}$ & $\begin{array}{l}0.0371 \\
(0.0250)\end{array}$ & $\begin{array}{l}0.0785 \\
(0.0408)\end{array}$ & $\begin{array}{l}0.112^{* *} \\
(0.0407)\end{array}$ \\
\hline age-squared & $\begin{array}{l}0.00543 \\
(0.00465)\end{array}$ & $\begin{array}{l}-(0.000357 \\
(0.000298)\end{array}$ & $\begin{array}{l}-\left(0.00103^{*}\right. \\
(0.000516)\end{array}$ & $\begin{array}{l}-0.0014^{* *} \\
(0.000522)\end{array}$ \\
\hline Years of education & $\begin{array}{l}0.154 \\
(0.253)\end{array}$ & $\begin{array}{l}0.00682 \\
(0.0189)\end{array}$ & $\begin{array}{l}0.0155 \\
(0.0206)\end{array}$ & $\begin{array}{l}0.0054 \\
(0.0200)\end{array}$ \\
\hline Wage-employed & $\begin{array}{l}-6.979^{* * *} \\
(1.368)\end{array}$ & & & \\
\hline Presence of adult female members & $\begin{array}{l}-5.074^{* * *} \\
(1.361)\end{array}$ & $\begin{array}{l}-0.067 \\
(0.102) \\
\end{array}$ & & \\
\hline Number of dependent members & $\begin{array}{l}1.672^{* * *} \\
(0.444)\end{array}$ & $\begin{array}{l}0.0296 \\
(0.0336)\end{array}$ & $\begin{array}{l}-0.0420 \\
(0.0433)\end{array}$ & $\begin{array}{l}-0.0822 \\
(0.0427)\end{array}$ \\
\hline Presence of adult male members & & & $\begin{array}{l}-(0.010 \\
(0.146)\end{array}$ & $\begin{array}{l}-0.154 \\
(0.142)\end{array}$ \\
\hline Asset Index & $\begin{array}{l}-25.78^{* * *} \\
(4.866)\end{array}$ & $\begin{array}{l}-0.933^{*} \\
(0.383) \\
\end{array}$ & $\begin{array}{l}1.043^{*} \\
(0.419)\end{array}$ & $\begin{array}{l}-0.226 \\
(0.414) \\
\end{array}$ \\
\hline Land Ownership & $\begin{array}{l}1.030 \\
(0.696) \\
\end{array}$ & $\begin{array}{l}0.282^{* * *} \\
(0.0762)\end{array}$ & $\begin{array}{l}-\left(0.519^{* *}\right. \\
(0.187)\end{array}$ & $\begin{array}{l}-0.053 \\
(0.087) \\
\end{array}$ \\
\hline High caste & $\begin{array}{l}1.399 \\
(2.421) \\
\end{array}$ & $\begin{array}{l}0.0766 \\
(0.1714) \\
\end{array}$ & $\begin{array}{l}-0.348 \\
(0.243) \\
\end{array}$ & $\begin{array}{l}-(0.60) 1^{* *} \\
(0.215)\end{array}$ \\
\hline Caste_Education & $\begin{array}{l}0.450 \\
(0.330)\end{array}$ & $\begin{array}{l}0.0212 \\
(0.0240)\end{array}$ & $\begin{array}{c}-0.0172 \\
(0.027)\end{array}$ & $\begin{array}{l}0.397 \\
(0.268)\end{array}$ \\
\hline Caste_Asset Index & $\begin{array}{l}-2.463 \\
(6.424) \\
\end{array}$ & $\begin{array}{l}-0.140 \\
(0.535) \\
\end{array}$ & $\begin{array}{l}0.273 \\
(0.630) \\
\end{array}$ & $\begin{array}{l}0.266 \\
(0.605) \\
\end{array}$ \\
\hline Location & $\begin{array}{l}7.303^{* * *} \\
(1.577) \\
\end{array}$ & $\begin{array}{l}0.654^{* * *} \\
(0.123)\end{array}$ & $\begin{array}{l}-0.208 \\
(0.137) \\
\end{array}$ & $\begin{array}{l}-0.327^{*} \\
(0.132) \\
\end{array}$ \\
\hline Mountain belt & $\begin{array}{l}-3.909 \\
(2.662) \\
\end{array}$ & $\begin{array}{l}0.574^{* *} \\
(0.181) \\
\end{array}$ & $\begin{array}{l}0.184 \\
(0.237) \\
\end{array}$ & $\begin{array}{l}0.475^{*} \\
(0.215) \\
\end{array}$ \\
\hline Hill belt & $\begin{array}{l}3.187^{*} \\
(1.245) \\
\end{array}$ & $\begin{array}{l}0.572^{* * *} \\
(0.092)\end{array}$ & $\begin{array}{l}0.0992 \\
(0.113) \\
\end{array}$ & $\begin{array}{l}0.214^{* *} \\
(0.110) \\
\end{array}$ \\
\hline
\end{tabular}




\begin{tabular}{|c|c|c|c|c|}
\hline Constant term & $\begin{array}{l}65.38^{* * *} \\
(7.928)\end{array}$ & $\begin{array}{l}-1.851^{* *} \\
(0.548)\end{array}$ & $\begin{array}{l}-2.577^{* *} \\
(0.808)\end{array}$ & $\begin{array}{l}-2.733^{* *} \\
(0.788)\end{array}$ \\
\hline $\mathrm{N}$ & 1079 & \multicolumn{3}{|l|}{977} \\
\hline R-squared/ Pseudo R- squared & 0.234 & & & \\
\hline Rho32 & & \multicolumn{3}{|l|}{$\begin{array}{l}-0.172^{*} \\
(0.0661)\end{array}$} \\
\hline Rho42 & & \multicolumn{3}{|l|}{$\begin{array}{l}-0.1314^{*} \\
(0.0626)\end{array}$} \\
\hline Rho43 & & \multicolumn{3}{|l|}{$\begin{array}{l}-0.274^{* * *} \\
(0.0707)\end{array}$} \\
\hline $\begin{array}{l}\text { Likelihood Ratio Test for } \\
\text { rho32=rho } 42=\text { rho } 43=0\end{array}$ & & \multicolumn{3}{|c|}{$\begin{array}{l}\text { Chi } 2(3)=27.95 \\
\text { Prob>chi2 }=0.000\end{array}$} \\
\hline
\end{tabular}

Standard errors in parenthesis.

${ }^{*} \mathrm{p}<0.05,{ }^{* *} \mathrm{p}<0.01,{ }^{* * *} \mathrm{p}<0.001$

Table 8: Work responsibilities of de jure heads, widows vs. non-widows

\begin{tabular}{|c|c|c|c|c|}
\hline & $\begin{array}{l}\text { Model 1: } \\
\text { hh_work }\end{array}$ & $\begin{array}{l}\text { Model 2: } \\
\text { s_ag }\end{array}$ & $\begin{array}{l}\text { Model 3: } \\
\text { s_n_ag }\end{array}$ & $\begin{array}{l}\text { Model 4: } \\
\text { wage }\end{array}$ \\
\hline Widow_head & $\begin{array}{l}1.453 \\
(2.043)\end{array}$ & $\begin{array}{l}-0.301 \\
(0.192) \\
\end{array}$ & $\begin{array}{l}0.0057 \\
(0.198)\end{array}$ & $\begin{array}{l}-0.102 \\
(0.210)\end{array}$ \\
\hline age & $\begin{array}{l}1.513^{* * *} \\
(0.287) \\
\end{array}$ & $\begin{array}{l}0.349 \\
(0.035) \\
\end{array}$ & $\begin{array}{l}0.1091^{*} \\
(0.0469)\end{array}$ & $\begin{array}{l}0.110^{*} \\
(0.044)\end{array}$ \\
\hline age-squared & $\begin{array}{l}-0.0176^{* *} \\
(0.00276)\end{array}$ & $\begin{array}{l}-0.00043 \\
(0.000349)\end{array}$ & $\begin{array}{l}-0.00124^{* *} \\
(0.000476)\end{array}$ & $\begin{array}{l}-\left(0.001^{* *}\right. \\
(0.0004)\end{array}$ \\
\hline Years of education & $\begin{array}{l}0.0604 \\
(0.310)\end{array}$ & $\begin{array}{c}-0.295^{*} \\
(0.137)\end{array}$ & $\begin{array}{l}0.0127 \\
(0.0374)\end{array}$ & $\begin{array}{l}0.079^{*} \\
(0.039)\end{array}$ \\
\hline Wage-employed & $\begin{array}{l}-3.608 \\
(1.989) \\
\end{array}$ & & & \\
\hline Presence of adult female members & $\begin{array}{l}-3.413^{*} \\
(1.668)\end{array}$ & $\begin{array}{l}-0.211 \\
(0.160) \\
\end{array}$ & & \\
\hline Number of dependent members & $\begin{array}{l}0.272 \\
(0.636)\end{array}$ & $\begin{array}{l}0.0850 \\
(0.0567)\end{array}$ & $\begin{array}{l}0.1061 \\
(0.0629)\end{array}$ & $\begin{array}{l}0.103 \\
(0.065)\end{array}$ \\
\hline Presence of adult male members & & & $\begin{array}{l}-0.048 \\
(0.167)\end{array}$ & $\begin{array}{l}-0.175 \\
(0.183)\end{array}$ \\
\hline Asset Index & $\begin{array}{l}-16.92^{* * *} \\
(5.526)\end{array}$ & $\begin{array}{l}-0.948 \\
(0.632) \\
\end{array}$ & $\begin{array}{l}1.023 \\
(0.603)\end{array}$ & $\begin{array}{l}-0.861 \\
(0.650)\end{array}$ \\
\hline Land Ownership & $\begin{array}{l}4.945^{*} \\
(1.927)\end{array}$ & $\begin{array}{l}0.511^{* *} \\
(0.173)\end{array}$ & $\begin{array}{l}-0.898^{* *} \\
(0.301)\end{array}$ & $\begin{array}{l}-0.605^{*} \\
(0.251)\end{array}$ \\
\hline High caste & $\begin{array}{l}4.227 \\
(2.890)\end{array}$ & $\begin{array}{l}0.189 \\
(0.2523)\end{array}$ & $\begin{array}{l}0.143 \\
(0.297)\end{array}$ & $\begin{array}{l}-0.490 \\
(0.307)\end{array}$ \\
\hline Caste_Education & $\begin{array}{l}-0.00573 \\
(0.314)\end{array}$ & $\begin{array}{l}0.270 \\
(0.139)\end{array}$ & $\begin{array}{l}-0.062 \\
(0.450)\end{array}$ & $\begin{array}{l}-0.010 \\
(0.043)\end{array}$ \\
\hline Caste_Asset Index & $\begin{array}{l}-5.098 \\
(6.371)\end{array}$ & $\begin{array}{l}-0.310 \\
(0.821)\end{array}$ & $\begin{array}{l}-0.335 \\
(0.822)\end{array}$ & $\begin{array}{l}0.335 \\
(0.852)\end{array}$ \\
\hline Location & $8.633^{* * *}$ & $0.457^{*}$ & 0.138 & $-0.704^{* *}$ \\
\hline
\end{tabular}




\begin{tabular}{|l|l|l|l|l|}
\hline & $(2.081)$ & $(0.199)$ & $(0.203)$ & $(0.205)$ \\
\hline Mountain belt & 3.259 & 0.147 & 0.167 & -0.370 \\
& $(3.351)$ & $(0.264)$ & $(0.299)$ & $(0.404)$ \\
\hline Hill belt & 2.958 & $0.486^{* *}$ & -0.0567 & 0.198 \\
& $(1.741)$ & $(0.163)$ & $(0.172)$ & $(0.183)$ \\
\hline Constant term & -1.301 & -1.407 & $-3.366^{* *}$ & -1.892 \\
& $(7.737)$ & $(0.907)$ & $(1.151)$ & $(0.006)$ \\
\hline $\mathrm{N}$ & 519 & 413 & \\
\hline R-squared/ Pseudo R- squared & 0.279 & & \\
\hline Rho32 & & -0.125 \\
& $(0.102)$ \\
\hline Rho42 & $\begin{array}{l}-0.004 \\
(0.111)\end{array}$ \\
\hline Rho43 & $\begin{array}{l}-0.494^{* * *} \\
(0.099)\end{array}$ \\
\hline $\begin{array}{l}\text { Likelihood Ratio Test for } \\
\text { rho32=rho42=rho43=0 }\end{array}$ & $\begin{array}{l}\text { Chi2(3) }=23.164 \\
\text { Prob>chi2=0.000 }\end{array}$ \\
\hline
\end{tabular}

Standard errors in parenthesis.

${ }^{*} \mathrm{p}<0.05,{ }^{* *} \mathrm{p}<0.01,{ }^{* * *} \mathrm{p}<0.001$ 